\title{
A Bibliometric Study on Innovation and Firm Performance: Building a Research Framework
}

\author{
Fabian Stein \\ University of Liechtenstein
}

In response to a rising interest in the connection between innovation and firm performance, this paper examines the body of research on this link and takes a closer look into the influences on innovation, firm performance or both. The basis for this study is a bibliometric analysis of 3,462 scientific publications. We identified 27 innovation domains with an influence on firm performance, showed the rising interest in the topic and found that most types of innovation have a positive impact on firm performance. We provide an overview of which indicators researchers used to measure innovativeness and firm performance and what methods they used to establish the link between the two. Additionally, we stress the importance of sustainable innovation and show that these also positively influence firm performance. In the end, we structure all research fronts into three different groups and based on that, develop a framework that visualizes research on innovation and firm performances.

Keywords: innovation, performance, bibliometrics

\section{INTRODUCTION AND MOTIVATION}

Innovation research has received considerable attention from the scientific community in the past years (Manders, Vries and Blind, 2016). The reasons for this are versatile. First, the ability to develop and implement innovations is a major influence on a firm's performance (Kauffeldt et al., 2012; Hashi and Stojčićc, 2013). On the other hand, this field receives a lot of attention from public players because they intend to decouple the degradation of the environment from economic growth (Working Group on Decoupling to the International Resource Panel, 2011) and organize a transition to a more sustainable society and economy (Adams et al., 2016) through innovation. This is also signaled by the United Nations (UN) Agenda for 2030 Sustainable Development Goals (UN General Assembly, 2015), of which has innovation is one component.

A considerable amount of literature has emerged that attempts to determine the exact effects of innovation on a firm. Analyses have been conducted regarding a variety of different fields in which innovation can be linked with firm performance, e.g. outsourcing (Awe, Kulangara and Henderson, 2018), strategic planning (Miller and Cardinal, 1994), data privacy (Martin, Borah and Palmatier, 2017) or green innovations (Bossle et al., 2016).

In publications which examine the relationship between innovativeness and firm performance, most authors base their research on their own empirical data rather than provide an overview of current research (Clercq, Thongpapanl and Dimov, 2011; Gunday et al., 2011). On the other hand, Varis and Littunen (2010) study different types of innovation and examine their impact on firm performance, focusing on small and 
medium enterprises, but ultimately use their own empirical data. An overview of current research on firm performance and innovation is provided by Rosenbusch, Brinckmann and Bausch (2011); however, they also only concentrate on small and medium enterprises. Bibliometric analyses in this field also do not provide an overview of different innovation domains, which we see as a field in which innovations with an influence on firm performance emerge. For example, Marzi et al. (2017) did a bibliometric analysis on process innovation in manufacturing, but did not research different domains or determine their importance.

Although several analyses have been done regarding different fields of firm performance, such as the ones mentioned above, the research lacks an overview on the domains that influence the relationship between innovativeness and firm performance according to the authors' knowledge. Likewise, there is also no systematic review of the indicators used to determine these domains' positive or negative influence, methods to examine the relationship or samples used to conduct these studies.

Therefore, researchers are neither able to compare different domains in a structured way nor determine their importance, detect gaps in current research or find new methods to conduct their own studies. This complex und unstructured field also makes it difficult to detect trends or new ideas where innovation domains influence a firm`s performance.

From a theoretical point of view, the positive influence of innovation on firm performance is explained by the resource-based view (RBV) (Wernerfelt, 1984; Barney, 1991). In this context, Lengnick-Hall (1992) identified innovation as a strategic resource that gives a firm a sustained competitive advantage in the market; in this case, financial firm performance, which is in accordance with empirical findings from the scientific community (Hashi and Stojčićc, 2013). Nevertheless, Wolfe (1994) points out that organizational innovative behavior and its antecedents and effects are is still not completely understood, which was repeated by Jin, Hewitt-Dundas and Thompson (2004) and Smith et al. (2008). Consequently, we aim to better understand research in the connection between innovation and firm performance indifferent fields of research, methods and results by answering the following research questions:

- How are publications on the relationship of innovation and firm performance clustered?

- What influences are being researched?

- Which influences are the focus of research in terms of number of publications?

- How exactly is research in this field being conducted? What methods and measures are being used?

- Is it possible to observe patterns in this field of research? Is it possible to deduct a framework?

\section{METHODOLOGY}

A bibliometric analysis was conducted to examine the proposed research questions. Bibliometrics uses mathematical and statistical methods to assess large amounts of literature (Bellis, 2009). It is an appropriate method for analyzing literature on innovation due to the ability to structure research fields (Meyer-Brötz et al., 2018).

First, a search string for the Web of Science Core Collection was developed based on the search strategy ideas of Stelzer et al. (2015). The search strategy was defined as: innovation AND "firm performance" and resulted in 3,462 scientific publications on the 9th of January 2020. The quotation marks are used to limit the search to publications with this exact combination of words in their title, abstract or assigned keywords. The following web of science categories were included in the search: Management OR Business OR Operations Research Management Science OR Business Finance. The search strategy was developed iteratively.

In the second step, we calculated the most frequent keywords of the articles. The keywords were analyzed based on labels given by editors of publishing journals. These keywords were then clustered using the Louvain algorithm (Blondel et al., 2008). The article publication years were subsequently divided into four periods to examine a temporal shift of interest. A keyword analysis is the first way to show the development of research during time periods (Hoppenstedt et al., 2018). Each time period was chosen to ensure that they all have an approximately equal number of keywords. 
In the third step, research fronts were calculated based on a hybrid similarity measure The hybrid similarity measure includes a lexical measure and a bibliographic coupling similarity measure, which was used as in Meyer-Brötz et al. (2018). Research fronts are growing research activities reported by publications on a certain research topic (Schiebel, 2012). The initial idea dates back to De Solla Price and Derek J. (1965), who represented scientific publications in networks, or mathematical graphs. In such a network, each node represents an article while the edges indicate the similarity (here, a hybrid similarity) of the nodes (Stelzer et al., 2015). The research fronts were clustered based on the mathematical graph of articles and their hybrid similarities with the help of the Louvain Clustering (Blondel et al., 2008). The final visualization of the research fronts was based on the Fruchterman-Reingold algorithm (Fruchterman and Reingold, 1991). The methodology for the creation of research frontiers is shown in Figure 1. In the remainder of this paper, the terms research fronts and clusters will be used interchangeably.

In the last step, we did a second iteration on chosen parts of our dataset where we selected papers based on their association to a certain research front, specified terms in their titles, their authors, publication year etc. and calculated new networks only with their bibliometric data to get a more refined view. For this paper, we did a second iteration for the research fronts evolving around sustainability and for papers that contain the term "innovation performance" in their titles.

\section{FIGURE 1}

\section{METHODOLOGY FOR THE CREATION OF RESEARCH FRONTIERS}

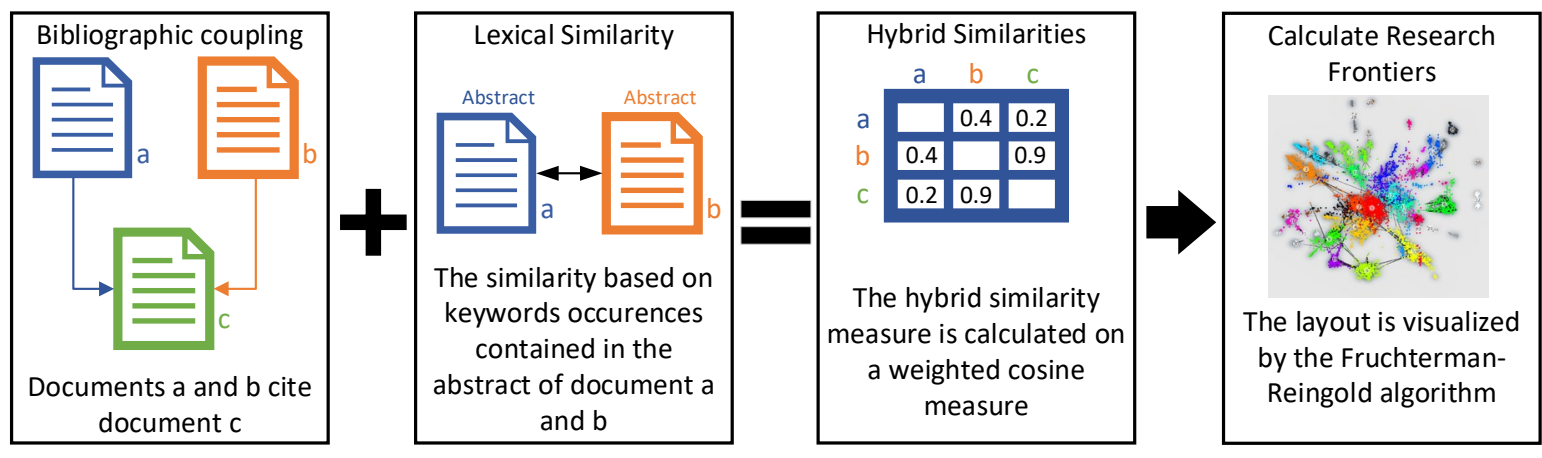

The results of the bibliometric analyses based on keywords and research fronts were summarized in a framework that is meant to visualize research in the field of innovation and firm performance. Literature provides several frameworks on the research between firm performance and innovation, which researches the influence of innovation on firm performance in a specific field, e.g. quality management (Prajogo and Sohal, 2001) or sustainability (Hansen, Grosse-Dunker and Reichwald, 2009). To our knowledge, a comprehensive framework on a higher level, including all fields of research, is missing in literature.

\section{BIBLIOMETRIC ANALYSIS}

The keyword analysis shows the top five percent most used keywords for all publications in our dataset. Figure 2 visualizes the results from this analysis, the keywords were grouped into different thematic areas, represented by different coloring. The cluster around the most used keyword, innovation (representing 571 publications), colored in green, consists of words describing the management and oversight of a firm, such as performance (250), knowledge management (89), organizational performance (86) and innovation performance (83) and other less used keywords. The second most used keyword, "firm performance" (representing 477 publications), colored in purple, is linked to keywords that are connected to a firm's strategy, e.g., entrepreneurial orientation (165), market orientation (99), internationalization (39) and other less used keywords. The other thematic areas are: innovation capabilities colored in red; firm capabilities colored in blue; human and intellectual capital colored in orange; ambidexterity colored in black; and business environment colored in grey. 


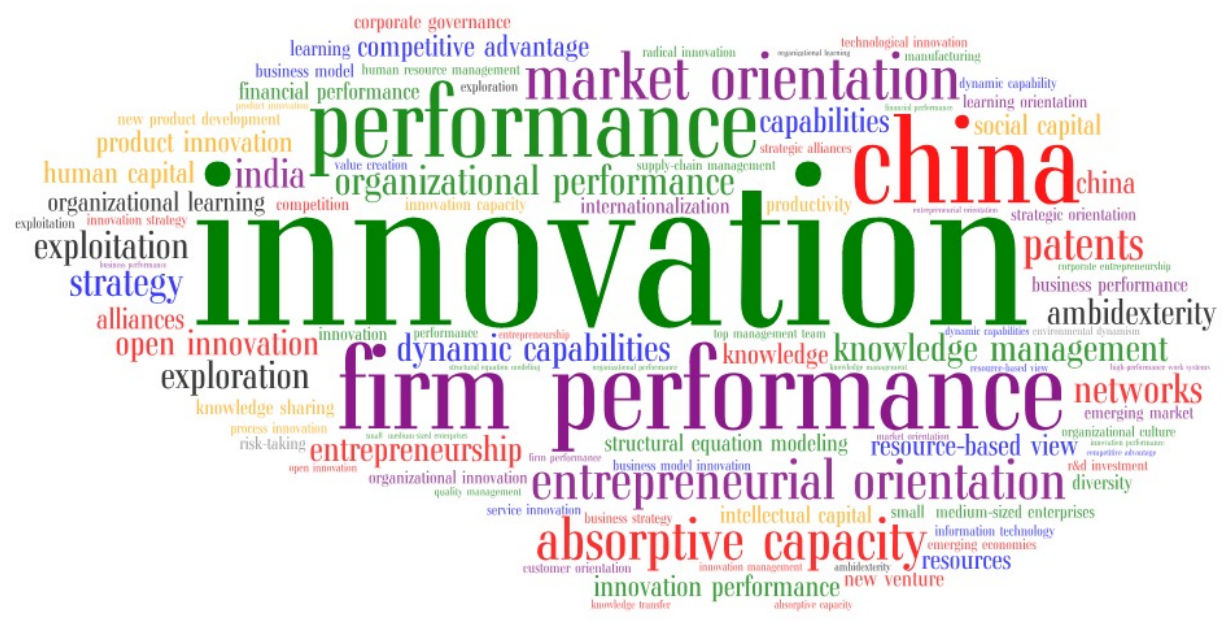

Additionally, we divided the keywords into four different time periods, 1990-2010, 2010-2014, 20142017 and 2017-2020, with approximately an equal number of keywords in each period. Table 1 shows the 15 most applied keywords for each period and how often they were used for publications. In all four periods, the keywords that were also our chosen search terms, i.e., innovation, firm performance and performance, were the top three most often used ones. Therefore, we will not include those terms in our further investigation on the trends and developments in the field since 1990, because we can't expect to gain any insights on the topic with them.

After the aforementioned top three used keywords, market orientation and knowledge management were the most used, in the first and longest period spanning 1990-2010. However, their importance declines in later times periods, where research instead focuses on the effect of innovations on firm performance in China (2014-2017) and then on the role of entrepreneurial orientation of a firm in the connection between innovation and firm performance (2017-2020). Also, absorptive capacity as an enabler of innovations effects on firm performance grew in importance from being the seventh most used term in the two time periods 1990 through 2014 to be the fifth most used term, right after entrepreneurial orientation in the time periods spanning 2014 through 2020.

TABLE 1

TOP 15 KEYWORDS OF EACH PERIOD

\begin{tabular}{|c|c|c|c|c|c|c|c|c|}
\hline & \multicolumn{2}{|l|}{$1990-2010$} & \multicolumn{2}{|c|}{$2010-2014$} & \multicolumn{2}{|c|}{ 2014-2017 } & \multicolumn{2}{|c|}{$2017-2019$} \\
\hline \# & Keywords & Use & Keywords & Use & Keywords & Use & Keywords & Use \\
\hline 1 & innovation & 103 & innovation & 174 & innovation & 217 & innovation & 212 \\
\hline 2 & $\begin{array}{l}\text { firm } \\
\text { performance }\end{array}$ & 90 & $\begin{array}{l}\text { firm } \\
\text { performance }\end{array}$ & 112 & $\begin{array}{l}\text { firm } \\
\text { performance }\end{array}$ & 195 & $\begin{array}{l}\text { firm } \\
\text { performance }\end{array}$ & 184 \\
\hline 3 & performance & 46 & performance & 73 & performance & 88 & performance & 93 \\
\hline 4 & $\begin{array}{l}\text { market } \\
\text { orientation }\end{array}$ & 25 & China & 38 & $\begin{array}{l}\text { entrepreneurial } \\
\text { orientation }\end{array}$ & 64 & $\begin{array}{l}\text { entrepreneurial } \\
\text { orientation }\end{array}$ & 86 \\
\hline 5 & $\begin{array}{l}\text { knowledge } \\
\text { management }\end{array}$ & 19 & $\begin{array}{l}\text { entrepreneurial } \\
\text { orientation }\end{array}$ & 32 & $\begin{array}{l}\text { absorptive } \\
\text { capacity }\end{array}$ & 46 & $\begin{array}{l}\text { absorptive } \\
\text { capacity }\end{array}$ & 53 \\
\hline 6 & $\begin{array}{l}\text { resource based } \\
\text { view }\end{array}$ & 19 & $\begin{array}{l}\text { organizational } \\
\text { performance }\end{array}$ & 30 & $\begin{array}{l}\text { innovation } \\
\text { performance }\end{array}$ & 40 & $\begin{array}{l}\text { innovation } \\
\text { performance }\end{array}$ & 45 \\
\hline
\end{tabular}




\begin{tabular}{|c|c|c|c|c|c|c|c|c|}
\hline 7 & $\begin{array}{l}\text { absorptive } \\
\text { capacity }\end{array}$ & 18 & $\begin{array}{l}\text { absorptive } \\
\text { capacity }\end{array}$ & 28 & $\begin{array}{l}\text { market } \\
\text { orientation }\end{array}$ & 38 & open innovation & 40 \\
\hline 8 & China & 16 & entrepreneurship & 23 & China & 36 & $\begin{array}{l}\text { knowledge } \\
\text { management }\end{array}$ & 39 \\
\hline 9 & $\begin{array}{l}\text { human } \\
\text { resource } \\
\text { management }\end{array}$ & 16 & $\begin{array}{l}\text { market } \\
\text { orientation }\end{array}$ & 23 & $\begin{array}{l}\text { knowledge } \\
\text { management }\end{array}$ & 35 & $\begin{array}{l}\text { dynamic } \\
\text { capabilities }\end{array}$ & 38 \\
\hline 10 & $\begin{array}{l}\text { competitive } \\
\text { advantage }\end{array}$ & 15 & $\begin{array}{l}\text { knowledge } \\
\text { management }\end{array}$ & 23 & open innovation & 34 & $\begin{array}{l}\text { organizational } \\
\text { performance }\end{array}$ & 37 \\
\hline 11 & $\begin{array}{l}\text { organizational } \\
\text { performance }\end{array}$ & 14 & $\begin{array}{l}\text { product } \\
\text { innovativeness }\end{array}$ & 21 & $\begin{array}{l}\text { competitive } \\
\text { advantage }\end{array}$ & 33 & China & 36 \\
\hline 12 & knowledge & 14 & $\begin{array}{l}\text { competitive } \\
\text { advantage }\end{array}$ & 21 & $\begin{array}{l}\text { dynamic } \\
\text { capabilities }\end{array}$ & 30 & entrepreneurship & 33 \\
\hline 13 & $\begin{array}{l}\text { entrepreneurial } \\
\text { orientation }\end{array}$ & 14 & $\begin{array}{l}\text { small-medium } \\
\text { sized enterprises }\end{array}$ & 18 & entrepreneurship & 28 & $\begin{array}{l}\text { product } \\
\text { innovation }\end{array}$ & 32 \\
\hline 14 & $\begin{array}{l}\text { organizational } \\
\text { learning }\end{array}$ & 13 & ambidexterity & 17 & $\begin{array}{l}\text { organizational } \\
\text { learning }\end{array}$ & 27 & $\begin{array}{l}\text { market } \\
\text { orientation }\end{array}$ & 31 \\
\hline 15 & $\begin{array}{l}\text { information } \\
\text { technology }\end{array}$ & 12 & $\begin{array}{l}\text { resource based } \\
\text { view }\end{array}$ & 17 & $\begin{array}{l}\text { organizational } \\
\text { performance }\end{array}$ & 27 & $\begin{array}{l}\text { financial } \\
\text { performance }\end{array}$ & 27 \\
\hline
\end{tabular}

In summary, the keyword analysis provides a preliminary idea on how the scientific community researches the connection between innovation and firm performance. Foremost, the keywords reflect our search term with innovation, firm performance and performance as most used labels for publications. After this, we see investigations in the effects of an entrepreneurial orientation or the role of absorptive capacity growing and becoming one of the main themes in research.

Next, we calculated the network of research fronts, as described in the Methodology. The whole network can be seen in Figure 3. Each research frontier was labelled manually according to the most frequently used terms in titles, abstracts and keywords and a screening of the most important publications in respect to how many times they were cited. We conducted this step manually because the probability of a false-positive cluster classification of papers increases with growing cluster size and not every article fits exactly to its cluster's topic (Hoppenstedt et al., 2018). We observed that every research front in the network represents a field that influences on either innovation, firm performance or both. 


\section{FIGURE 3 \\ RESEARCH FRONTS “COMPLETE DATASET"}

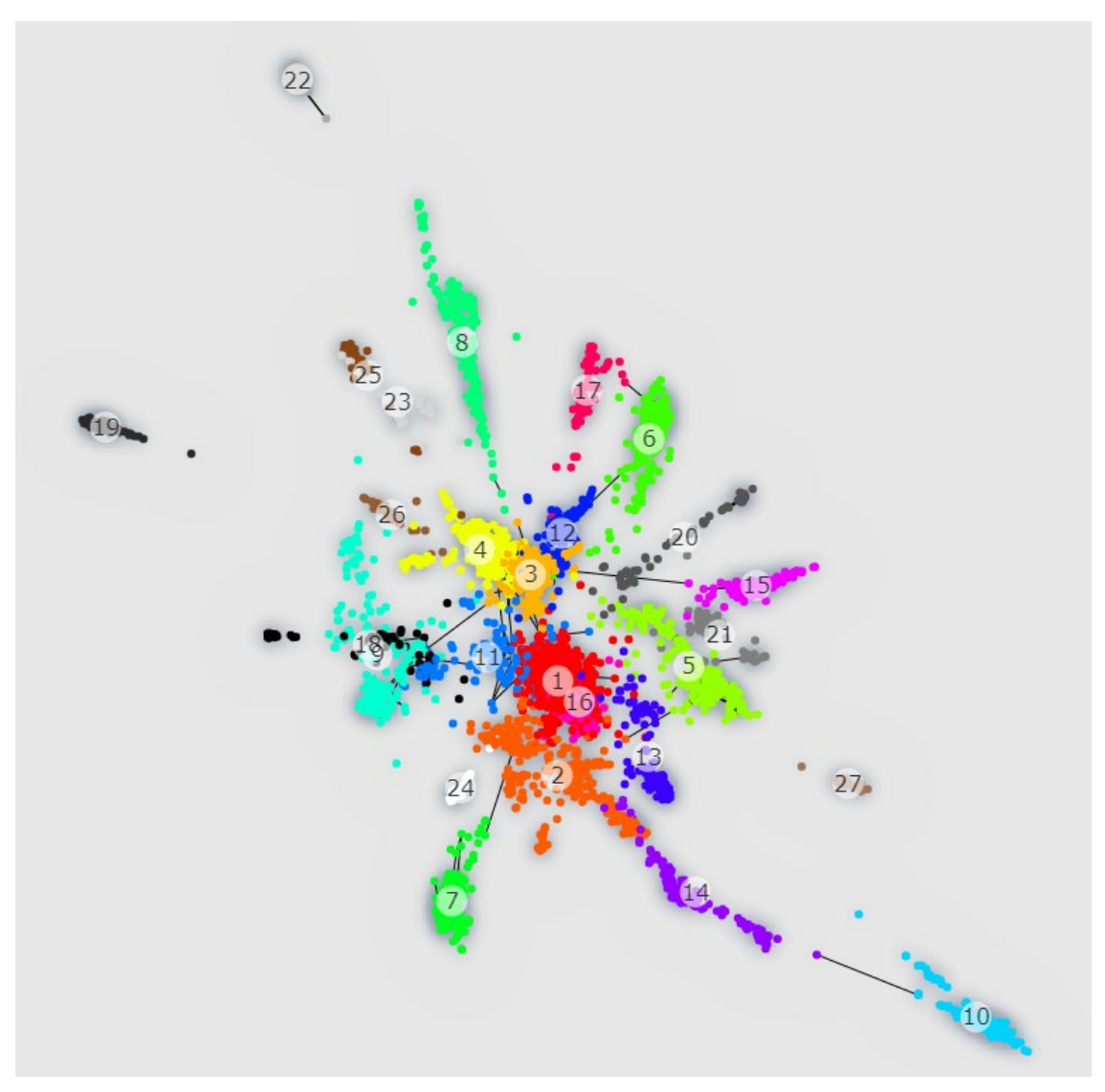

Next, we analyzed the five largest research fronts to better understand how they are built up. Additionally, and regarding the current importance of the topic in business and society, as explained in the introduction, we did a second iteration on the research fronts: Sustainability and Corporate Social Responsibility (CSR).

In terms of number of publications, the most attention in the scientific community was given to papers in the research front Business Models, which encompasses the interrelation of innovation, business models and firm performance. Gatautis, Vaiciukynaite and Tarute (2019) investigated how business model innovations effect the innovativeness and firm performance of small and medium companies. Their survey amongst Lithuanian firms showed that business model innovations in firms have positive effect on both a firm's innovativeness and its overall firm performance. The same positive effect on firm performance was found by Popa, Soto-Acosta and Perez-Gonzalez (2018), who, also by survey, found that new e-business models improve firm performance by reducing operational costs. Further, other papers found business innovation to be significantly linked to the number of new product sales.

The second largest research front, Knowledge Management \& Patents, focuses on how management of internal knowledge and patents is related to firm performance and firm innovativeness. Research on knowledge management in this cluster is very conclusive. Several publications investigate its influence on either innovation or firm performance and find that the planned and active management of knowledge in companies is beneficial for a its performance (Nguyen et al., 2018; Abubakar et al., 2019). The role of patenting, on the other hand, is more disputed. Artz et al. (2010) found that the announcements of new products was positively related to a firm's performance, measured as return on assets (ROA), which is negatively correlated with the number of patents a firm is granted in a year. These findings are being 
challenged by Andries and Faems (2013), who concluded that patenting activities actually do improve a firm's performance, measured as their profit margin.

Entrepreneurship is the third biggest cluster and mostly consists of research on the influence of entrepreneurial orientation either on a firm's innovativeness or its performance. Several different authors find evidence that entrepreneurial behavior in firms, e.g., taking risks or innovative actions, improve their performance (Lumpkin and Dess, 2001; Avlonitis and Salavou, 2007; Alvarez-Torres, Lopez-Torres and Schiuma, 2019). Additionally, Shan, Song and Ju (2016) identified innovation speed, the time passed between initial development and commercialization of a product, as a mediator between the introduction of new business models and firm performance.

The research front Strategic Orientation contains publications that research the role a firm's strategic orientation plays in the connection between innovation and firm performance. The influence of the different orientations on a firm are highly disputed in the scientific community; the work of Aloulou (2019) shows that entrepreneurial orientation of a firm has a positive influence on new product development, which is not enhanced by either market and technology orientations. On the other hand, Ashrafi and Zare Ravasan (2018) found a positive association between the degree of market orientation and firm performance, mediated by their innovativeness. The third most researched strategy was customer orientation, which was proven to be beneficial for a firm's performance (Brockman, Jones and Becherer, 2012).

The last detailed analysis is on the research front Innovation Collaboration, which shows the same pattern as the preceding ones. Papers here research how different kinds of firm collaborations effects their innovativeness, their firm performance or moderates the relationship of these two. For the number of R\&D alliances a firm takes part in, Gan and Xu (2019) found out that they at first reduce innovation output in terms of new products, but over time, have a more positive influence as firm's learn how to manage their alliances. These findings are also affirmed by Faems, Janssens and Neyens (2012). Fang et al. (2016) also add that a central position in an innovation network fosters sales of new developed products and Fernandes et al. (2019) also emphasizes that innovation cooperation with competitors has a positive impact on a firm's innovation-related activities and performance.

TABLE 2

\section{RESEARCH FRONTS}

\begin{tabular}{|c|c|c|c|}
\hline$\#$ & Cluster Name / Domains & Relevant Paper & Publications \\
\hline 1 & Business Models & $\begin{array}{l}\text { Fifteen Years of Research on Business } \\
\text { Model Innovation: How Far Have We Come, } \\
\text { and Where Should We Go? (Foss and Saebi, } \\
\text { 2017) }\end{array}$ & 561 \\
\hline 2 & Knowledge Management & $\begin{array}{l}\text { Gaining from scientific knowledge: the role } \\
\text { of knowledge accumulation and knowledge } \\
\text { combination (Kuo, Wu and Lin, 2019) }\end{array}$ & 265 \\
\hline 3 & Entrepreneurship & $\begin{array}{l}\text { The dual nature of innovative activity: How } \\
\text { entrepreneurial orientation influences } \\
\text { innovation generation and adoption (Pérez- } \\
\text { Luño, Wiklund and Cabrera, 2011) }\end{array}$ & 255 \\
\hline 4 & Strategic Orientation & $\begin{array}{l}\text { Customer relationship management } \\
\text { capabilities and social media technology use: } \\
\text { Consequences on firm performance (Foltean, } \\
\text { Trif and Tuleu, 2019) }\end{array}$ & 226 \\
\hline 5 & Innovation Collaboration & $\begin{array}{l}\text { Influence of alliance portfolio diversity on } \\
\text { innovation performance: the role of internal } \\
\text { capabilities of value creation (Chung, Kim } \\
\text { and Kang, 2019) }\end{array}$ & 210 \\
\hline
\end{tabular}




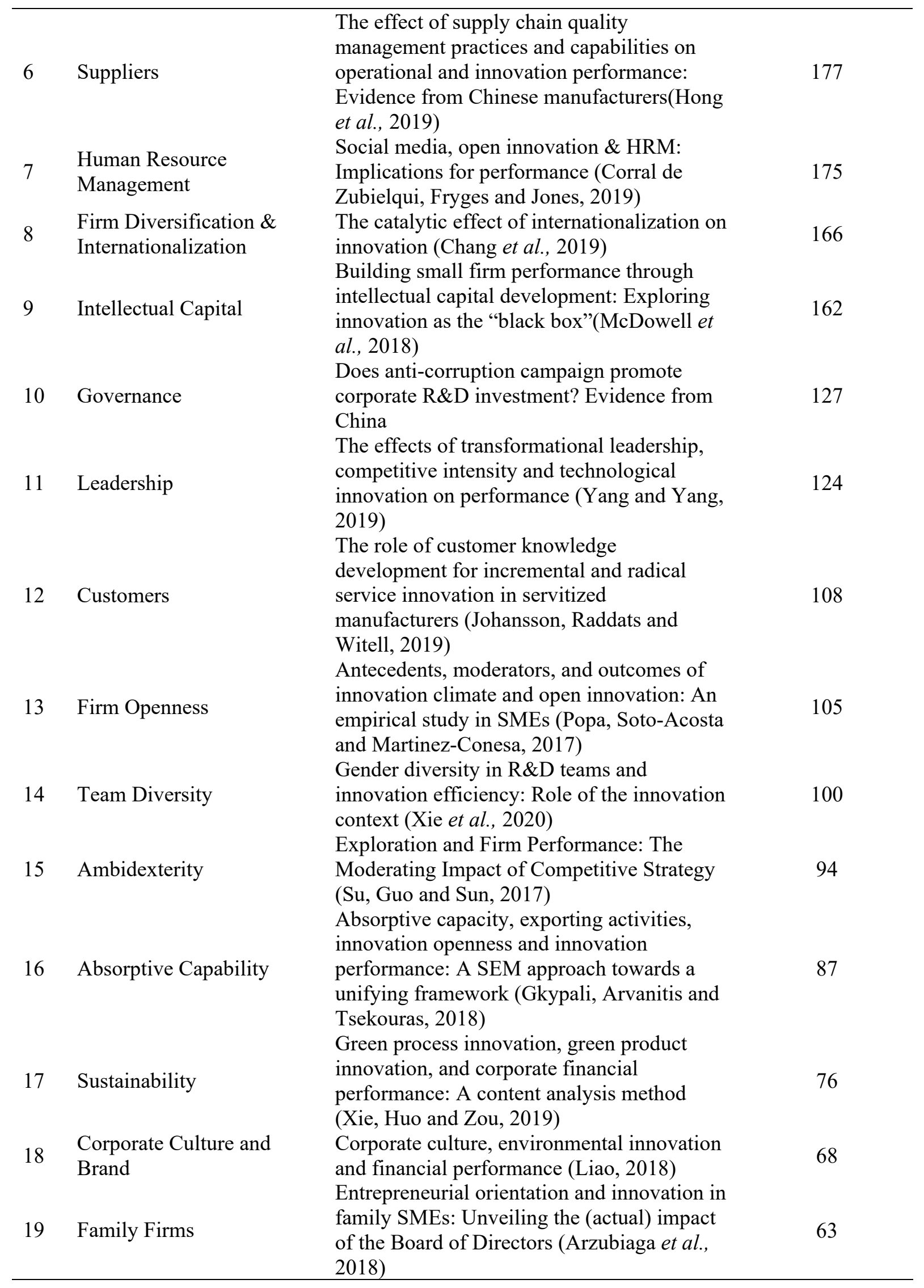




\begin{tabular}{|c|c|c|c|}
\hline 20 & $\begin{array}{l}\text { Corporate Social } \\
\text { Responsibility }\end{array}$ & $\begin{array}{l}\text { The influence of corporate social } \\
\text { responsibility on investment efficiency and } \\
\text { innovation (Cook et al., 2019) }\end{array}$ & 59 \\
\hline 21 & Firm Capabilities & $\begin{array}{l}\text { Developing organizational agility in product } \\
\text { innovation: the roles of IT capability, KM } \\
\text { capability, and innovative climate (Cai et al., } \\
\text { 2019) }\end{array}$ & 59 \\
\hline 22 & Organizational Slack & $\begin{array}{l}\text { Slack resources, exploratory and exploitative } \\
\text { innovation and the performance of small } \\
\text { technology-based firms at incubators } \\
\text { (Soetanto and Jack, 2018) }\end{array}$ & 46 \\
\hline 23 & Platforms \& Ecosystems & $\begin{array}{l}\text { Disruption in Platform-Based Ecosystems } \\
\text { (Ozalp, Cennamo and Gawer, 2018) }\end{array}$ & 40 \\
\hline 24 & Quality Management & $\begin{array}{l}\text { The impact of hard and soft quality } \\
\text { management and proactive behaviour in } \\
\text { determining innovation performance (Escrig- } \\
\text { Tena et al., 2018) }\end{array}$ & 32 \\
\hline 25 & Political Involvement & $\begin{array}{l}\text { Antecedents and Innovation Performance } \\
\text { Implications of MNC Political Ties in the } \\
\text { Chinese Automotive Supply Chain (Jean, } \\
\text { Sinkovics and Zagelmeyer, 2018) }\end{array}$ & 30 \\
\hline 26 & Exports & $\begin{array}{l}\text { Entrepreneurial orientation and export } \\
\text { intensity: Examining the interplay of } \\
\text { organizational learning and innovation } \\
\text { (Fernández-Mesa and Alegre, 2015) }\end{array}$ & 29 \\
\hline 27 & Firm Location & $\begin{array}{l}\text { Knowledge exchange in clusters: The } \\
\text { contingent role of regional inventive } \\
\text { concentration (Vestal and Danneels, 2018) }\end{array}$ & 27 \\
\hline
\end{tabular}

For the analysis of the research fronts Sustainability and Corporate Social Responsibility, we extracted their data and calculated a new network that only contains papers from these two research fronts. The extracted data show that the field is strongly growing, especially in recent years. Figure 4 shows how many papers were written on sustainability or CSR, to play a role in the connection of innovation and firm performance. We found two things remarkable: first, that the attention on this topic was very low before the year of 2010, where nine papers in total were written in this field and second, there was a strong growth from 2014 to 2015. While four articles were published in 2014, 18 were published in 2015, which means a growth of $350 \%$ in just one year. Both findings underline the growing importance of this topic in business research. 


\section{FIGURE 4 \\ TEMPORAL DEVELOPMENT SUSTAINABILITY AND CORPORATE SOCIAL RESPONSIBILITY}

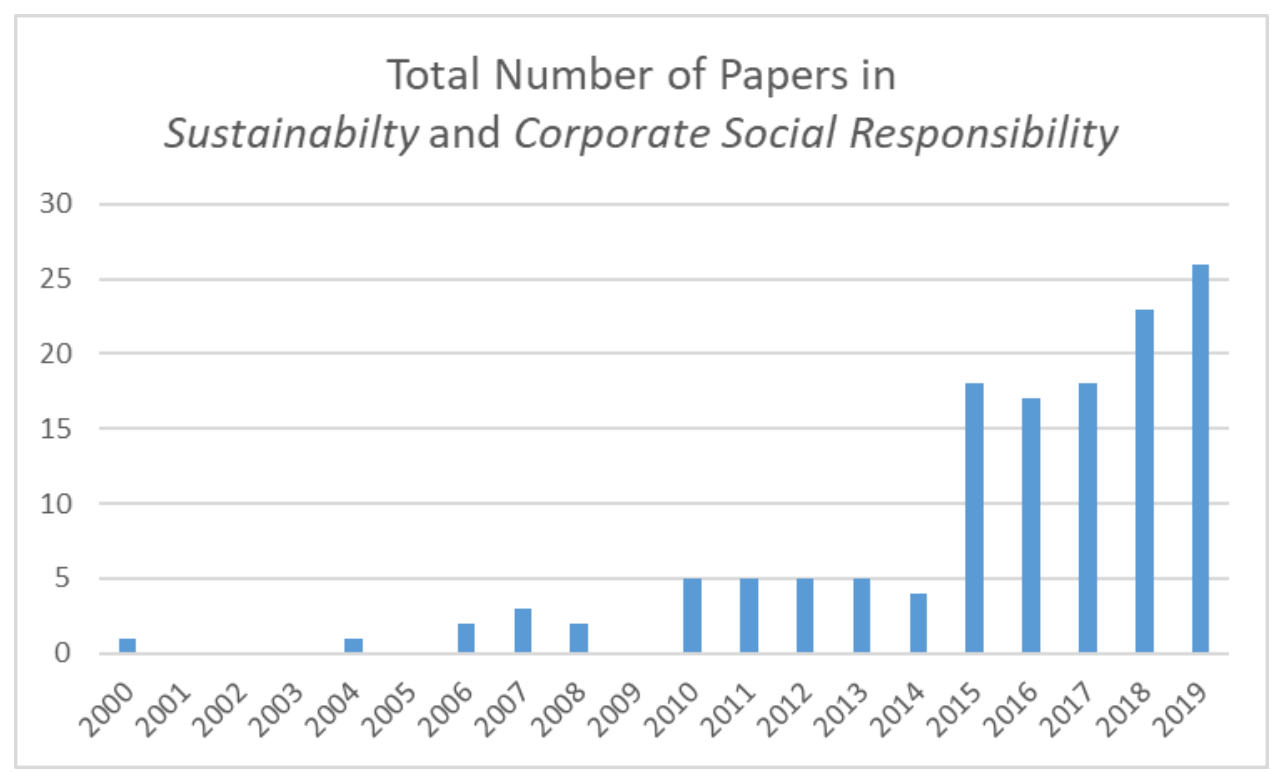

The network analysis of the research fronts shows the same pattern as with other research fronts. Researchers try to understand the exact role of sustainability in the connection of innovation and firm performance. Other than research on the direct influence of sustainability on firm performance, which is very inconclusive (Awaysheh et al., 2020), researchers find a lot of evidence for the positive effect of sustainable, or green innovation, on firm performance in different ways. Publications find a positive influence of CSR, or sustainability activities, on the generation of patents or patent citations (Cook et al., 2019) and determine a positive effect of green product innovation and green process innovation on firm performance (Tang et al., 2018; Tariq, Badir and Chonglerttham, 2019).

The last step of our analysis was to further understand the direct, non-intermediary influence of innovation on firm performance, i.e. what effects researchers found, what measures they used and what methods they applied. Therefore, we searched the database for papers with the term "firm performance" in their titles to refine the number of papers that only concentrate on the impact of different innovation domains on firm performance. This search resulted in 579 papers, which can be divided into 16 research fronts, as shown in Figure 5. This step was necessary because our original search, which used the terms "innovation" and "firm performance", contained papers that had these two search terms either in title, abstract, author keywords or Web of Science keywords (2019). Therefore, the papers may not have focused on firm performance, but only mentioned it. By concentrating on papers that have "firm performance" only in their titles, we received only papers that focused on it. 


\section{FIGURE 5 \\ RESEARCH FRONTS "FIRM PERFORMANCE"}

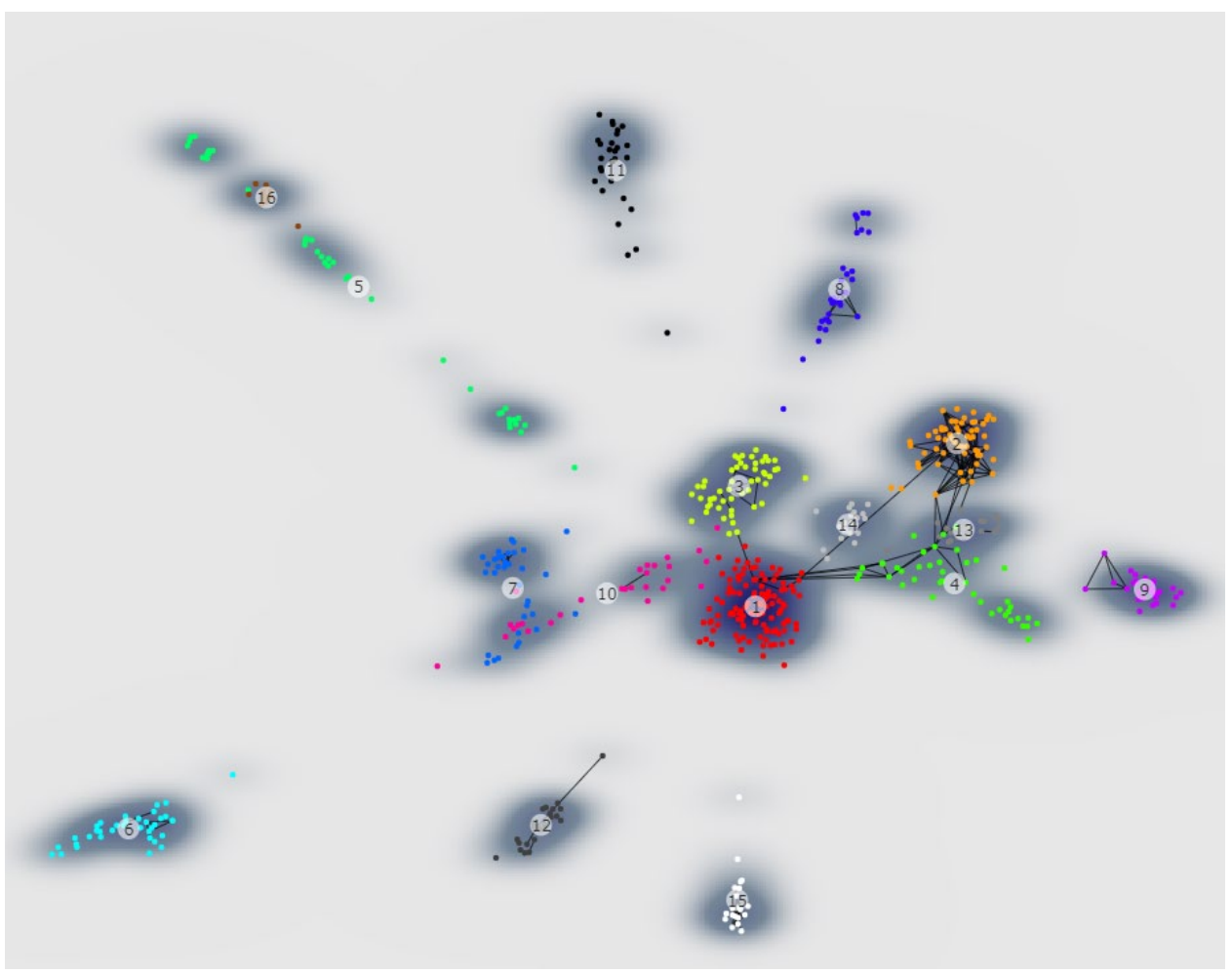

Analysis of the most cited relevant papers in these clusters reveal that most researchers found a positive impact of innovation and similar activities on firm performance. However, there were also exceptions to this. For example, Artz et al. (2010) found a negative connection between the number of patents and firm performance in terms of Return on Assets and firm growth. Further, Atalay, Anafarta and Sarvan (2013) found no significant or positive influence of organizational and marketing innovation on firm performance, even though they were able to prove a positive impact of technological innovation on firm performance. Similar results were found by Koellinger (2008), who stated that product and service innovations are the only innovations positively associated with firm performance. According to the mentioned sources, innovations of processes do not have a positive relationship with firm performance. Protogerou, Caloghirou and Lioukas (2012) showed that dynamic capabilities, the ability of a firm to handle changing environments (Barreto, 2010), does not have a direct and significant influence on firm performance, but rather impacts operational capabilities, which in turn positively effect firm performance. In the field of Sustainable Strategy, two noteworthy observations were made: Lee and Min (2015) found that while green research and development is positively associated with financial performance, it has a negative relationship with carbon emissions, meaning it contributes to reductions; in contrast to the results we found in the research fronts Sustainability and Corporate Social Responsibility, Doran and Ryan (2016) found that one form of eco-innovations, the improved recycling of products after use, reduces a firm's productivity. Another interesting observation was made by Bong Choi and Williams (2013), who examined the influence of innovation and firm performance in China and Korea and discovered that the relationship between these two topics was strongly influenced by the country in which a firm is situated.

Additionally, we also examined the indicators that were used to describe innovation and those that were used to describe firm performance. The latter were often represented by profitability measures, e.g., Return on Equity, Return on Assets or Return on Investment (Cho and Pucik, 2005), growth indicators, e.g., sales growth or market share growth (Wang, Chang and Shen, 2015), firm value figures, e.g., Tobins Q (Hung 
and Chou, 2013) and employee-related performance indicators, e.g., value added per employee or sales generated from new products per employee (Belderbos, Carree and Lokshin, 2004).

To measure innovation activities in a firm, authors also used a wide variety of indicators. For example, R\&D activities were used, e.g., R\&D ratio (Shin, Kraemer and Dedrick, 2009), measured R\&D expenses divided by sales, or man power in the R\&D department (Sher and Yang, 2005), as well as patent-related activities, e.g., the number of patents granted to a firm (Lin and Chang, 2015) or patent citations (Bloom and van Reenen, 2002). Also, new product performance, seen as new product sales, profitability or market share (Olavarrieta and Friedmann, 2008), was used to measure innovation. In addition to these indicators, authors also examined different determinants that were closely related to the innovation domain they examined, e.g., knowledge assets measured as a percentage of technical and professional staff in the workforce, the implementation of target costing (Huang et al., 2012) or external partner collaborations (Chen, Tsou and Huang, 2009).

Regression analysis, especially ordinary least square regressions, was mostly used to determine the relationship between innovations and firm performance (Kalkan, Bozkurt and Arman, 2014; Lee and Min, 2015; Hatak et al., 2016).

\section{BUILDING A FRAMEWORK}

In the first step to build a framework, we classified each research front as one of three groups, which we called Firm Domains. First, the research fronts forming the group Firm Activities focus on interactions of a firm with its environment, e.g. Business Models, Innovation Collaboration or Suppliers. Second, the group, Firm Characteristics, consists of research fronts focusing on traits given to a firm, e.g. Firm Diversification \& Internationalization, Governance or Firm Openness. The third group, Firm Skills, is formed by research fronts that focus on certain internal activities or qualities of a firm, e.g. Knowledge Management \& Patents, Entrepreneurship or Strategic Orientation. The three domains and all their research fronts are listed in Table 3.

TABLE 3

FIRM DOMAINS IN RESEARCH ON INNOVATION AND FIRM PERFORMANCE

\begin{tabular}{|c|c|c|c|c|c|}
\hline \multicolumn{2}{|c|}{ Firm Activities } & \multicolumn{2}{|c|}{ Firm Characteristics } & \multicolumn{2}{|c|}{ Firm Skills } \\
\hline$\#$ & Cluster Name & $\#$ & Cluster Name & $\#$ & Cluster Name \\
\hline 1 & Business Models & & $\begin{array}{l}\text { Firm Diversification \& } \\
\text { Internationalization }\end{array}$ & 2 & $\begin{array}{l}\text { Knowledge Management } \\
\text { \& Patents }\end{array}$ \\
\hline 5 & Innovation Collaboration & 10 & Governance & 3 & Entrepreneurship \\
\hline 6 & Suppliers & 13 & Firm Openness & 4 & Strategic Orientation \\
\hline 7 & $\begin{array}{l}\text { Human Resource } \\
\text { Management }\end{array}$ & 14 & Team Diversity & 9 & Intellectual Capital \\
\hline 12 & Customers & 18 & $\begin{array}{l}\text { Corporate Culture \& } \\
\text { Brand }\end{array}$ & 11 & Leadership \\
\hline 17 & Sustainability & 19 & Family Firms & 15 & Ambidexterity \\
\hline 20 & $\begin{array}{l}\text { Corporate Social } \\
\text { Responsibility }\end{array}$ & 27 & Firm Location & 16 & Absorptive Capacity \\
\hline 23 & $\begin{array}{l}\text { Platforms and } \\
\text { Ecosystems }\end{array}$ & & & 21 & Firm Capabilities \\
\hline 25 & Political Involvement & & & 22 & Organizational Slack \\
\hline 26 & Exports & & & 24 & Quality Management \\
\hline
\end{tabular}


Throughout the whole network of research fronts, we discovered certain patterns on how research in this field is being conducted. We generally found four different patterns: one group of papers investigated the direct influence of innovation activities on firm performance (Chen and Ibhagui, 2019), another one the influence of a certain domain on firm performance (Gahlawat and Kundu, 2019), the third direct or indirect influence of innovation on a certain firm domain or vice versa (Bocquet et al., 2019) and the last group investigated mediation or moderation effects of either innovation in the relationship between a firm domain and firm performance or of a firm domain in the connection between innovation and firm performance (ElKassar and Singh, 2019). The framework is visualized in Figure 6.

\section{FIGURE 6 \\ FRAMEWORK “RESEARCH ON INNOVATION AND FIRM PERFORMANCE”}

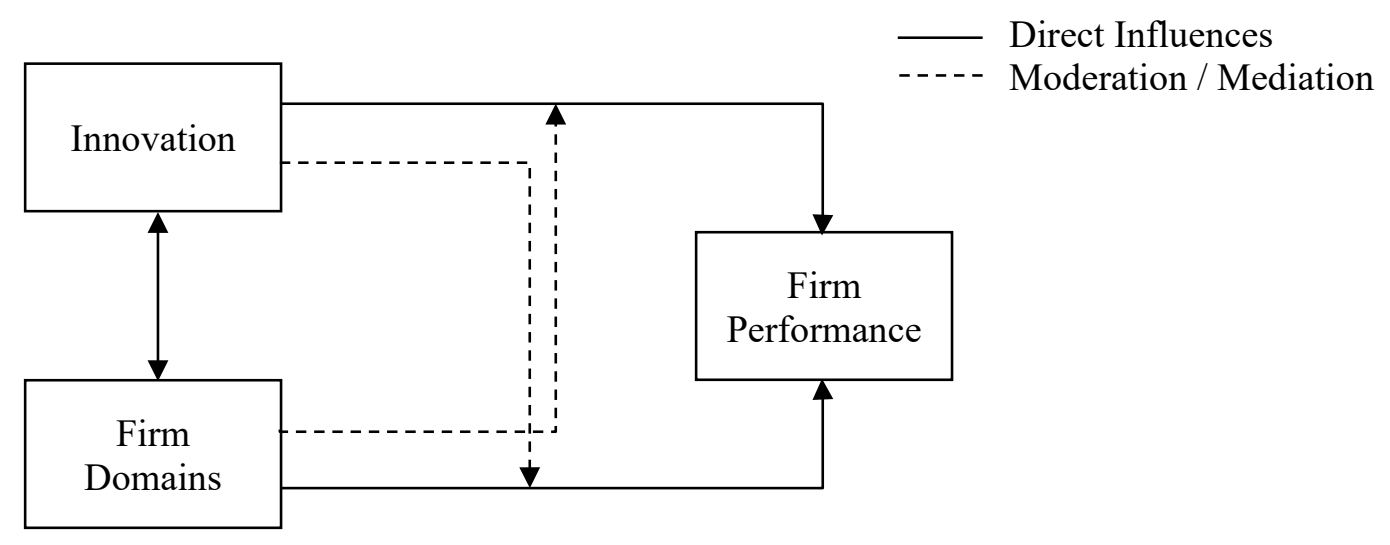

\section{DISCUSSION}

The bibliometric analysis structured the vague field of research fields in innovation and firm performance, as seen in Table 3. We identified three Firm Domains, based on 28 research fronts that appeared in a bibliometric analysis, ordered them according to their importance in the scientific community and identified papers that established connections between the identified domains, innovation and firm performance. We then used our findings to develop a framework of how research is conducted. As pointed out in in the Bibliometric Analysis, most domains have a positive influence on firm performance; only observations related to very specific elements of the fields Patents (Artz et al., 2010) and Sustainability (Doran and Ryan, 2016) were found to have a negative influence on firm performance. The research was especially focused on Business Model (561 publications), Knowledge Management \& Patents (265), Entrepreneurship (255), Strategic Orientation (226) and Innovation Collaboration (210). Fields that receive the least attention from the scientific community are Political Involvement (30), Exports (29) and Firm Location (27). The indicators used to determine the relationship between innovation and firm performance were mostly basic profitability measures, such as Return on Assets or Return on Interest, while indicators to measure innovation were mostly related to process outcomes, patents or employee-based figures. We identified regression analysis as the main method to examine the relationship between innovation and firm performance.

The relationship between innovation and firm performance is widely examined, but research is divided into small niches. Academics have explored the influence of single domains on firm performance but have not provided a clear overview of what domains influence firm performance in terms of innovation. Our work presents a structured overview on research in the connection between innovation and firm performance on two different levels.

First, we provided a list of the 27 different research fronts in this field and gave explanations on how they are being researched. We then divided them into three different firm domains according to their relationship to firms. Following this, we set up a framework to demonstrate how scholars research the 
relationship between innovation and firm performance. We found out that they either investigate the direct influence of innovation and firm performance, in the direct influence of one of our research fronts on innovation or firm performance, in moderating/mediating effects of innovation or the research streams on the relationship with the other and a firm's performance.

In Table 2, we provide a structured overview of the 27 different innovation fields of firm performance, which is helpful for practitioners in many ways. First, it illustrates which topics are important in terms of innovation and firm performance and shows that, besides a few exceptions, most have a positive influence. With this, managers can now examine their own company and discover which domains are already considered and which ones are not or are unfit for their firm. They can use the indicators that were used to draw connections to measure their own innovation inputs and outputs.

In academia, the outline can be used as a framework for further research in the precise effects of the different domains of firm performance. We provided a clear list that illustrates the most important topics researched in connection with innovation and firm performance and put them in order according to scientific interest. Additionally, we showed which methods are being used to research the connection between the different domains and firm performance. Researchers can now either use these methods for their own research or use the list to identify gaps and apply new and innovative methods.

Two main problems can be drawn from the limitations of the dataset. First, the search string resulted in papers that contain the terms innovation and "firm performance" in their titles, abstracts or keywords, which does not necessarily mean that they examined the relationship between these two entities. Second, the database is not comprehensive; there are still publications that do not appear in the Web of Science database.

\section{REFERENCES}

Abubakar, A.M., Elrehail, H., Alatailat, M.A., \& Elçi, A. (2019). Knowledge management, decisionmaking style and organizational performance. Journal of Innovation \& Knowledge, 4(2), 104 114.

Adams, R., Jeanrenaud, S., Bessant, J., Denyer, D., \& Overy, P. (2016). Sustainability-oriented Innovation: A Systematic Review. International Journal of Management Reviews, 18(2), 180 205.

Aloulou, W.J. (2019). Impacts of strategic orientations on new product development and firm performances. European Journal of Innovation Management, 22(2), 257-280.

Alvarez-Torres, F.J., Lopez-Torres, G.C., \& Schiuma, G. (2019). Linking entrepreneurial orientation to SMEs' performance. Management Decision, 57(12), 3364-3386.

Andries, P., \& Faems, D. (2013). Patenting Activities and Firm Performance: Does Firm Size Matter? Journal of Product Innovation Management, 30(6), 1089-1098.

Artz, K.W., Norman, P.M., Hatfield, D.E., \& Cardinal, L.B. (2010). A Longitudinal Study of the Impact of R\&D, Patents, and Product Innovation on Firm Performance. Journal of Product Innovation Management, 27(5), 725-740.

Arzubiaga, U., Kotlar, J., de Massis, A., Maseda A., \& Iturralde, T. (2018). Entrepreneurial orientation and innovation in family SMEs: Unveiling the (actual) impact of the Board of Directors. Journal of Business Venturing, 33(4), 455-469.

Ashrafi, A., \& Ravasan, A.Z. (2018). How market orientation contributes to innovation and market performance: The roles of business analytics and flexible IT infrastructure. Journal of Business \& Industrial Marketing, 33(7), 970-983.

Atalay, M., Anafarta, N., \& Sarvan, F. (2013). The Relationship between Innovation and Firm Performance: An Empirical Evidence from Turkish Automotive Supplier Industry. Procedia Social and Behavioral Sciences, 75, 226-235.

Avlonitis, G.J., \& Salavou, H.E. (2007). Entrepreneurial orientation of SMEs, product innovativeness, and performance. Journal of Business Research, 60(5), 566-575.

Awaysheh, A., Heron, R.A., Perry, T., \& Wilson, J.I. (2020). On the Relation Between CSR and Financial Performance. Strategic Management Journal. 
Awe, O.A., Kulangara, N., \& Henderson, D.F. (2018). Outsourcing and firm performance: A metaanalysis. Journal of Strategy and Management, 11(3), 371-386.

Barney, J. (1991). Firm Resources and Sustained Competitive Advantage. Journal of Management, 17(1), 99-120.

Barreto, I. (2010). Dynamic Capabilities: A Review of Past Research and an Agenda for the Future. Journal of Management, 36(1), 256-280.

Belderbos, R., Carree, M., \& Lokshin, B. (2004). Cooperative R\&D and firm performance. Research Policy, 33(10), 1477-1492.

Blondel, V.D., Guillaume, J-L., Lambiotte, R., \& Lefebvre, E. (2008). Fast unfolding of communities in large networks. Journal of Statistical Mechanics: Theory and Experiment, (10), P10008.

Bloom, N., \& van Reenen, J. (2002). Patents, Real Options and Firm Performance. The Economic Journal, 112(478), C97-C116.

Bocquet, R., Le Bas, C., Mothe, C., \& Poussing, N. (2019). Strategic CSR for innovation in SMEs: Does diversity matter? Long Range Planning, 52(6), 101913.

Bong Choi, S., \& Williams, C. (2013). Innovation and firm performance in Korea and China: A crosscontext test of mainstream theories. Technology Analysis \& Strategic Management, 25(4), 423 444.

Bossle, M.B., de Barcellos, M.D., Vieira, L.M., \& Sauvée, L. (2016). The drivers for adoption of ecoinnovation. Journal of Cleaner Production, 113, 861-872.

Brockman, B.K., Jones, M.A., \& Becherer, R.C. (2012). Customer Orientation and Performance in Small Firms: Examining the Moderating Influence of Risk-Taking, Innovativeness, and Opportunity Focus. Journal of Small Business Management, 50(3), 429-446.

Cai, Z., Liu, H., Huang, Q., \& Liang, L. (2019). Developing organizational agility in product innovation: The roles of IT capability, KM capability, and innovative climate. $R \& D$ Management, 49(4), 421-438.

Chang, C-H., Chang, C-H., Hsu, P-K., \& Yang, S-Y. (2019). The catalytic effect of internationalization on innovation. European Financial Management, 25(4), 942-977.

Chen, J-S., Tsou, H.T., \& Huang, A.Y-H. (2009). Service Delivery Innovation. Journal of Service Research, 12(1), 36-55.

Chen, Y., \& Ibhagui, O.W. (2019). R\&D-firm performance nexus: New evidence from NASDAQ listed firms. The North American Journal of Economics and Finance, 50, 101009.

Cho, H-J., \& Pucik, V. (2005). Relationship between innovativeness, quality, growth, profitability, and market value. Strategic Management Journal, 26(6), 555-575.

Chung, D., Kim, M.J., \& Kang, J. (2019). Influence of alliance portfolio diversity on innovation performance: The role of internal capabilities of value creation. Review of Managerial Science, 13(5), 1093-1120.

Cook, K.A., Romi, A.M., Sánchez, D., \& Sánchez, J.M. (2019). The influence of corporate social responsibility on investment efficiency and innovation. Journal of Business Finance \& Accounting, 46(3-4), 494-537.

Corral de Zubielqui, G., Fryges, H., \& Jones, J. (2019). Social media, open innovation \& HRM: Implications for performance. Technological Forecasting and Social Change, 144, 334-347.

de Clercq, D., Thongpapanl, N., \& Dimov, D. (2011). The Moderating Role of Organizational Context on the Relationship Between Innovation and Firm Performance. IEEE Transactions on Engineering Management, 58(3), 431-444.

De Solla Price, D.J. (1965). Networks of Scientific Papers. Science, (149), 510-515.

Doran, J., \& Ryan, G. (2016). The Importance of the Diverse Drivers and Types of Environmental Innovation for Firm Performance. Business Strategy and the Environment, 25(2), 102-119.

El-Kassar, A-N., \& Singh, S.K. (2019). Green innovation and organizational performance: The influence of big data and the moderating role of management commitment and HR practices. Technological Forecasting and Social Change, 144, 483-498. 
Escrig-Tena, A.B., Segarra-Ciprés, M., García-Juan, B., \& Beltrán-Martín, I. (2018). The impact of hard and soft quality management and proactive behaviour in determining innovation performance. International Journal of Production Economics, 200, 1-14.

Faems, D., Janssens, M., \& Neyens, I. (2012). Alliance Portfolios and Innovation Performance. Group \& Organization Management, 37(2), 241-268.

Fang, E., Lee, J., Palmatier, R., \& Han, S. (2016). If It Takes a Village to Foster Innovation, Success Depends on the Neighbors: The Effects of Global and Ego Networks on New Product Launches. Journal of Marketing Research, 53(3), 319-337.

Fernandes, C.I., Ferreira, J.J., Veiga, P.M., \& Marques, C. (2019). The effects of coopetition on the innovation activities and firm performance. Competitiveness Review: An International Business Journal, 29(5), 622-645.

Fernández-Mesa, A., \& Alegre, J. (2015). Entrepreneurial orientation and export intensity: Examining the interplay of organizational learning and innovation. International Business Review, 24(1), 148156.

Foltean, F.S., Trif, S.M., \& Tuleu, D.L. (2019). Customer relationship management capabilities and social media technology use: Consequences on firm performance. Journal of Business Research, $104,563-575$.

Foss, N.J., \& Saebi, T. (2017). Fifteen Years of Research on Business Model Innovation. Journal of Management, 43(1), 200-227.

Fruchterman, T.M.J., \& Reingold, E.M. (1991). Graph drawing by force-directed placement. Software: Practice and Experience, 21(11), 1129-1164.

Gahlawat, N., \& Kundu, S.C. (2019). Progressive human resource management and firm performance. International Journal of Organizational Analysis, 27(3), 471-493.

Gan, W., \& Xu, X. (2019). Does anti-corruption campaign promote corporate R\&D investment? Evidence from China. Finance Research Letters, 30, 292-296.

Gatautis, R., Vaiciukynaite, E., \& Tarute, A. (2019). Impact of business model innovations on SME's innovativeness and performance. Baltic Journal of Management, 14(4), 521-539.

Gkypali, A., Arvanitis, S., \& Tsekouras, K. (2018). Absorptive capacity, exporting activities, innovation openness and innovation performance: A SEM approach towards a unifying framework. Technological Forecasting and Social Change, 132, 143-155.

Gunday, G., Ulusoy, G., Kilic, K., \& Alpkan, L. (2011). Effects of innovation types on firm performance. International Journal of Production Economics, 133(2), 662-676.

Hansen, E., Grosse-Dunker, F., \& Reichwald, R. (2009). Sustainability Innovation Cube - A Framework To Evaluate Sustainability Oriented Innovations. International Journal of Innovation Management, 13(04), 683-713.

Hashi, I., \& Stojčićc, N. (2013). The impact of innovation activities on firm performance using a multistage model: Evidence from the Community Innovation Survey 4. Research Policy, 42(2), 353366.

Hatak, I., Kautonen, T., Fink, M., \& Kansikas, J. (2016). Innovativeness and family-firm performance: The moderating effect of family commitment. Technological Forecasting and Social Change, $102,120-131$.

Hong, J., Liao, Y., Zhang, Y., \& Yu, Z. (2019). The effect of supply chain quality management practices and capabilities on operational and innovation performance: Evidence from Chinese manufacturers. International Journal of Production Economics, 212, 227-235.

Hoppenstedt, B., Pryss, R., Stelzer, B., Meyer-Brötz, F., Kammerer, K., Treß, A., \& Reichert, M. (2018). Techniques and Emerging Trends for State of the Art Equipment Maintenance Systems-A Bibliometric Analysis. Applied Sciences, 8(6), 916.

Huang, H-C., Lai, M-C., Kao, M-C., \& Chen, Y-C. (2012). Target Costing, Business Model Innovation, and Firm Performance: An Empirical Analysis of Chinese Firms. Canadian Journal of Administrative Sciences / Revue Canadienne des Sciences de l'Administration, 29(4), 322-335. 
Hung, K-P., \& Chou, C. (2013). The impact of open innovation on firm performance: The moderating effects of internal R\&D and environmental turbulence. Technovation, 33(10-11), 368-380.

Jean, R.J.B., Sinkovics, R.R., \& Zagelmeyer, S. (2018). Antecedents and Innovation Performance Implications of MNC Political Ties in the Chinese Automotive Supply Chain. Management International Review, 58(6), 995-1026.

Jin, Z., Hewitt-Dundas, N., \& Thompson, N.J. (2004). Innovativeness and performance: Evidence from manufacturing sectors. Journal of Strategic Marketing, 12(4), 255-266.

Johansson, A.E., Raddats, C., \& Witell, L. (2019). The role of customer knowledge development for incremental and radical service innovation in servitized manufacturers. Journal of Business Research, 98, 328-338.

Kalkan, A., Bozkurt, Ö.Ç., \& Arman, M. (2014). The Impacts of Intellectual Capital, Innovation and Organizational Strategy on Firm Performance. Procedia - Social and Behavioral Sciences, $150,700-707$.

Kauffeldt, J., Brecht, L., Schallmo, D., \& Welz, K. (2012). Measuring Innovation Capability in German ICT-companies by using DEA-Models. Proceedings of the 5th ISPIM Innovation Symposium: Stimulating Innovation: Challenges for Management, Science \& Technology.

Koellinger, P. (2008). The relationship between technology, innovation, and firm performanceEmpirical evidence from e-business in Europe. Research Policy, 37(8), 1317-1328.

Kuo, C-I., Wu, C-H., \& Lin, B-W. (2019). Gaining from scientific knowledge: The role of knowledge accumulation and knowledge combination. R\&D Management, 49(2), 252-263.

Lee, K-H., \& Min, B. (2015). Green R\&D for eco-innovation and its impact on carbon emissions and firm performance. Journal of Cleaner Production, 108, 534-542.

Lengnick-Hall, C.A. (1992). Innovation and Competitive Advantage: What We Know and What We Need to Learn. Journal of Management, 18(2), 399-429.

Liao, Z. (2018). Corporate culture, environmental innovation and financial performance. Business Strategy and the Environment, 27(8), 1368-1375.

Lin, C., \& Chang, C-C. (2015). A patent-based study of the relationships among technological portfolio, ambidextrous innovation, and firm performance. Technology Analysis \& Strategic Management, 27(10), 1193-1211.

Lumpkin, G.T., \& Dess, G.G. (2001). Linking two dimensions of entrepreneurial orientation to firm performance. Journal of Business Venturing, 16(5), 429-451.

Manders, B., de Vries, H.J., \& Blind, K. (2016). ISO 9001 and product innovation: A literature review and research framework. Technovation, 48-49, 41-55.

Martin, K.D., Borah, A., \& Palmatier, R.W. (2017). Data Privacy: Effects on Customer and Firm Performance. Journal of Marketing, 81(1), 36-58.

Marzi, G., Dabić, M., Daim, T., \& Garces, E. (2017). Product and process innovation in manufacturing firms: A 30-year bibliometric analysis. Scientometrics, 113(2), 673-704.

McDowell, W.C., Peake, W.O., Coder, L., \& Harris, M.L. (2018). Building small firm performance through intellectual capital development: Exploring innovation as the "black box". Journal of Business Research, 88, 321-327.

Meyer-Brötz, F., Stelzer, B., Schiebel, E., \& Brecht, L. (2018). Mapping the technology and innovation management literature using hybrid bibliometric networks. International Journal of Technology Management, 77(4), 235.

Miller, C.C., \& Cardinal, L.B. (1994). Strategic Planning and Firm Performance: A Synthesis of More Than Two Decades of Research. Academy of Management Journal, 37(6), 1649-1665.

Nguyen, N.P., Ngo, L.V., Bucic, T., \& Phong, N.D. (2018). Cross-functional knowledge sharing, coordination and firm performance: The role of cross-functional competition. Industrial Marketing Management, 71, 123-134.

Olavarrieta, S., \& Friedmann, R. (2008). Market orientation, knowledge-related resources and firm performance. Journal of Business Research, 61(6), 623-630. 
Ozalp, H., Cennamo, C., \& Gawer, A. (2018). Disruption in Platform-Based Ecosystems. Journal of Management Studies, 55(7), 1203-1241.

Pérez-Luño, A., Wiklund, J., \& Cabrera, R.V. (2011). The dual nature of innovative activity: How entrepreneurial orientation influences innovation generation and adoption. Journal of Business Venturing, 26(5), 555-571.

Popa, S., Soto-Acosta, P., \& Martinez-Conesa, I. (2017). Antecedents, moderators, and outcomes of innovation climate and open innovation: An empirical study in SMEs. Technological Forecasting and Social Change, 118, 134-142.

Popa, S., Soto-Acosta, P., \& Perez-Gonzalez, D. (2018). An investigation of the effect of electronic business on financial performance of Spanish manufacturing SMEs. Technological Forecasting and Social Change, 136, 355-362.

Prajogo, D.I., \& Sohal, A.S. (2001). TQM and innovation: A literature review and research framework. Technovation, 21(9), 539-558.

Protogerou, A., Caloghirou, Y., \& Lioukas, S. (2012). Dynamic capabilities and their indirect impact on firm performance. Industrial and Corporate Change, 21(3), 615-647.

Rosenbusch, N., Brinckmann, J., \& Bausch, A. (2011). Is innovation always beneficial? A meta-analysis of the relationship between innovation and performance in SMEs. Journal of Business Venturing, 26(4), 441-457.

Schiebel, E. (2012). Visualization of research fronts and knowledge bases by three-dimensional areal densities of bibliographically coupled publications and co-citations. Scientometrics, 91(2), 557566.

Shan, P., Song, M., \& Ju, X. (2016). Entrepreneurial orientation and performance: Is innovation speed a missing link? Journal of Business Research, 69(2), 683-690.

Sher, P.J., \& Yang, P.Y. (2005). The effects of innovative capabilities and R\&D clustering on firm performance: The evidence of Taiwan's semiconductor industry. Technovation, 25(1), 33-43.

Shin, N., Kraemer, K.L., \& Dedrick, J. (2009). R\&D, Value Chain Location and Firm Performance in the Global Electronics Industry. Industry \& Innovation, 16(3), 315-330.

Smith, M., Busin, M., Ball, P., \& van der Meer, R. (2008). Factors Influencing an Organisation's Ability to Manage Innovation: A Structured Literature Review and Conceptual Model. International Journal of Innovation Management, 12(04), 655-676.

Soetanto, D., \& Jack, S.L. (2018). Slack resources, exploratory and exploitative innovation and the performance of small technology-based firms at incubators. The Journal of Technology Transfer, 43(5), 1213-1231.

Stelzer, B., Meyer-Brötz, F., Schiebel, E., \& Brecht, L. (2015). Combining the scenario technique with bibliometrics for technology foresight: The case of personalized medicine. Technological Forecasting and Social Change, 98, 137-156.

Su, Z., Guo, H., \& Sun, W. (2017). Exploration and Firm Performance: The Moderating Impact of Competitive Strategy. British Journal of Management, 28(3), 357-371.

Tang, M., Walsh, G., Lerner, D., Fitza, M.A., \& Li, Q. (2018). Green Innovation, Managerial Concern and Firm Performance: An Empirical Study. Business Strategy and the Environment, 27(1), 39 51.

Tariq, A., Badir, Y., \& Chonglerttham, S. (2019). Green innovation and performance: Moderation analyses from Thailand. European Journal of Innovation Management, 22(3), 446-467.

UN General Assembly. (2015). Transforming our World: The 2030 Agenda for Sustainable Development $A / R E S / 70 / 1$.

Varis, M., \& Littunen, H. (2010). Types of innovation, sources of information and performance in entrepreneurial SMEs. European Journal of Innovation Management, 13(2), 128-154.

Vestal, A., \& Danneels, E. (2018). Knowledge exchange in clusters: The contingent role of regional inventive concentration. Research Policy, 47(10), 1887-1903. 
Wang, C-H., Chang, C-H., \& Shen, G.C. (2015). The effect of inbound open innovation on firm performance: Evidence from high-tech industry. Technological Forecasting and Social Change, 99, 222-230.

Web of Science Core Collection Help. (2019). Retrieved May 6, 2019, from http://images.webofknowledge.com/WOKRS532MR24/help/WOS/hs_topic.html

Wernerfelt, B. (1984). A resource-based view of the firm. Strategic Management Journal, 5(2), 171-180.

Wolfe, R.A. (1994). Organizational Innovation: Review, Critique and Suggested Research Directions. Journal of Management Studies, 31(3), 405-431.

Working Group on Decoupling to the International Resource Panel. (2011). Decoupling natural resource use and environmental impacts from economic growth. Kenya, UNEP.

Xie, L., Zhou, J., Zong, Q., \& Lu, Q. (2020). Gender diversity in R\&D teams and innovation efficiency: Role of the innovation context. Research Policy, 49(1), 103885.

Xie, X., Huo, J., \& Zou, H. (2019). Green process innovation, green product innovation, and corporate financial performance: A content analysis method. Journal of Business Research, 101, 697-706.

Yang, H., \& Yang, J. (2019). The effects of transformational leadership, competitive intensity and technological innovation on performance. Technology Analysis \& Strategic Management, 31(3), 292-305. 